\title{
Synergies among social safeguards in FLEGT and REDD+ in Cameroon
}

\section{Tegegne, Yitagesu T.}

2017-02

Tegegne , Y T , Ramcilovic-Suominen, S , Kalame , F B , Visseren-Hamakers , I J , Lindner , M \& Kanninen , M 2017 , ' Synergies among social safeguards in FLEGT and REDD+ in Cameroon ' , Forest Policy and Economics , vol. 75 , pp. 1-11 . https://doi.org/10.1016/j.forpol.2016.11.005

http://hdl.handle.net/10138/308004

https://doi.org/10.1016/j.forpol.2016.11.005

cc_by_nc_nd

acceptedVersion

Downloaded from Helda, University of Helsinki institutional repository.

This is an electronic reprint of the original article.

This reprint may differ from the original in pagination and typographic detail.

Please cite the original version. 
Yitagesu T. Tegegne ${ }^{1,2 *}$, Sabaheta Ramcilovic-Suominen ${ }^{3}$, Kalame Fobissie ${ }^{2}$, Ingrid J. Visseren-Hamakers ${ }^{4}$, Marcus Lindner ${ }^{1}$, Markku Kanninen ${ }^{2}$

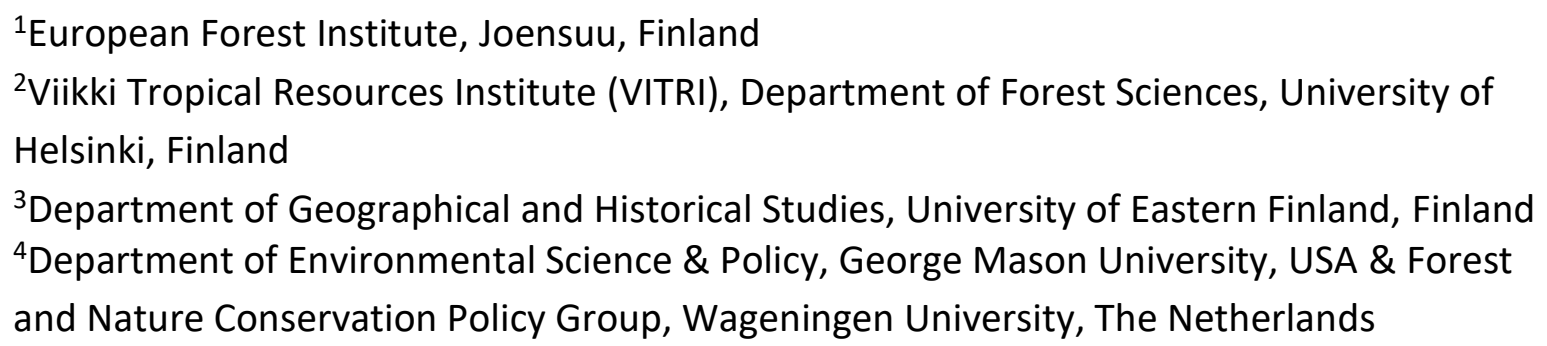

\section{Abstract}

Two key international policy processes have been developed to combat illegal logging and promote the contribution of forests to climate change mitigation in developing countries: the European Union's Action Plan on Forest Law Enforcement, Governance and Trade (FLEGT) and its Voluntary Partnership Agreements (VPAs), and the United Nations Framework Convention on Climate Change policy on Reducing Emissions from Deforestation and Forest Degradation (REDD+). The implementation of these policies raises concerns about unintended adverse effects on the environment and local peoples' livelihoods. To prevent such effects, both processes involve developing country-level safeguards, so that they 'do no harm'. This paper presents (i) a comparison of the social safeguards of the FLEGT-VPA and REDD+ processes and an explanation of their commonalities and differences, and (ii) an exploration of the potential synergies and the challenges to realizing them. The three main research methods used in the study were semi-structured interviews, content analysis of policy documents, and focus group discussions with local communities and indigenous peoples in south and east Cameroon. Our analysis shows that whereas FLEGT-VPA includes legality-based safeguards with legally binding monitoring and reporting obligations, REDD+ adopts a right-based approach to safeguards. Potential synergies between the two approaches were identified. The synergies lie in the participatory nature of the process of designing benefit sharing mechanisms, strengthening forest and land tenure, and defining the criteria and indicators in FLEGT-VPA and REDD+ safeguards. However, realizing the synergies is challenging, given the existing political economy of Cameroon.

Key words: policy implementation, participatory management, forest governance, tenure, Cameroon

\footnotetext{
"Corresponding author. Tel: +358 45896 0929; e-mail addresses: yitagesu.tekle@efi.int , yitag2007@yahoo.com
} 
Deforestation and forest degradation are the key causes of an increasing reduction of the world's forest and important contributors to greenhouse gas (GHG) emissions (Achard et al., 2014), with illegal logging being an important cause of deforestation and forest degradation (e.g. through harvesting premature forest or harvesting more trees than legally allowed), thereby contributing to GHG emissions (Tacconi, 2007).

Two major international policy processes have been established to address the problem of illegal logging, and of deforestation and forest degradation: the European Union's (EU) Action Plan on Forest Law Enforcement, Governance and Trade (FLEGT) and the United Nations policy on Reducing Emissions from Deforestation and Forest Degradation (REDD+). The FLEGT Action Plan focuses on the timber trade and the enforcement of forest laws and regulations as a way to combat illegal logging (European Commission, 2003). Bilaterally negotiated Voluntary Partnership Agreements (VPAs) with timber-producing countries that export to the EU are a major component of the Action Plan (European Commission, 2003). REDD+ is a multilateral initiative under the United Nations Framework Convention on Climate Change (UNFCCC) to reduce deforestation and forest degradation, as a way to reduce GHG emissions from forest and land use. REDD+ is based on the concept of incentivizing developing countries to reduce emissions in the forest and land-use sector (Angelsen et al., 2012). In parallel to the development of REDD+ under the UNFCCC, the World Bank's Forest Carbon Partnership Facility (FCPF) and the UN-REDD Programme have been supporting developing countries in their efforts to "get ready" for REDD+. FLEGT and REDD+ are two distinct policy processes, operating under different design and implementation strategies. However, both aspire to bring about a positive change in governance (Angelsen et al., 2012; European Commission, 2003), and both face significant and similar challenges in implementation (Corbera \& Schroeder, 2011; Ramcilovic-Suominen \& Hansen, 2012; Visseren-Hamakers et al., 2012).

Despite the implementation challenges, there is a strong commitment to further the development and implementation of the processes at the global, national and subnational levels. This commitment of the two processes lie not only in the stated policy goals, but also in the anticipation that their effective implementation will promote sustainable forest management, generate non-carbon benefits, and address worries related to poor governance, land tenure, biodiversity conservation, effective participation, benefit sharing and poverty alleviation (McDermott et al., 2012; Ros-Tonen et al., 2013). This is why stakeholders have pushed for the incorporation in these policy processes of so-called safeguards, addressing both environmental and social issues (Jagger et al., 2014; McDermott et al., 2012). While an emerging body of literature has focused on the interactions between FLEGT and REDD+ more generally (Broekhoven \& Wit, 2014; Ochieng et al., 2013; Tegegne et al., 2014), a comparatively smaller amount of research has focused on the relationships among the social safeguards in those two processes (McDermott et al., 2012). This is important, because in order to ensure that a country safeguard system is developed and implemented efficiently, synergies with other safeguard systems of related processes in the 
country should be explored (Jagger et al., 2014; McDermott et al., 2012; Rey et al., 2013). Furthermore, consideration of the synergies among the safeguards of related processes can avoid duplication of efforts and enhance economies of scale. Against this backdrop, this study addressed the following questions:

- What are the commonalities and differences between the social safeguard approaches of FLEGT-VPA and REDD+ in Cameroon, and how can these similarities and differences be explained?

- What are the potential synergies between the FLEGT-VPA and REDD+ social safeguards, and what challenges stand in the way of realizing these synergies?

It is hoped that the comparison of safeguard approaches will contribute to learning, improvements and further guidance on the development and implementation of safeguards in the FLEGT-VPA and REDD+ processes. Moreover, before one is able to develop synergies between related policies, understanding commonalities and differences and the reasons for the overlaps are necessary (Duguma et al., 2014; Gehring \& Oberthür, 2009; McDermott et al., 2012). Such analysis is particular necessary to identify and inform relevant stakeholders about aspects of environmental and social challenges where the processes can (not) work together and why (Rey et al., 2013). The early lessons learnt in Cameroon can be beneficial to the 15 countries that are currently negotiating or implementing a FLEGT-VPA and participating in REDD+, and help in the development of the theoretical debate on social safeguards.

Section 2 introduces the conceptual dimensions of social safeguards and section 3 presents overview of the FLEGT-VPA and REDD+ processes in Cameroon and the research methods. Section 4 presents the research findings and section 5 discusses the key findings of the study. Finally, section 6 outlines the main concluding remarks.

\section{Conceptual framework: Approaches to social safeguards}

The concept of social safeguards in general has its origins in the World Bank's safeguards policies and in the United Nations (UN) system in the 1980s (Hall, 2007). The World Bank's approach - which was later also adopted by the Global Environmental Facility (GEF) - focuses on doing no harm. This approach is also known as the mitigation approach (McDermott et al., 2012), so as to indicate its reactive - as opposed to proactive - nature. It focuses on addressing adverse impacts resulting from investment and development activities (EMGUNEP, 2010), and encompasses aspects such as working conditions, pollution, health and security (Ros-Tonen et al., 2013). The UN's approach to social safeguards pursues the idea of preventing undue harm (EMG-UNEP, 2010), thus taking a proactive stand. It puts greater emphasis on the promotion of rights and social benefits, and is thus also referred as the rightbased approach (McDermott et al., 2012; Ros-Tonen et al., 2013).

In addition to these two approaches, social safeguards have recently been revisited in the policy discourse surrounding REDD+. Countries undertaking REDD+ activities are requested to develop country-level approaches that enable them to respond to the requirements outlined 
in the recent UNFCCC agreements concerning social and environmental risks. The provisions of social and environmental safeguards in REDD+ are explained in a number of decisions. First, the Cancun Agreement (1/CP.16) acknowledges the need to address national forest governance shortcomings and mitigate any potential adverse social and environmental effects that could prevent REDD+ from achieving its long-term goals (UNFCCC, 2011). Second, in 2011, the UNFCCC COP 17 in Durban set up a Safeguard Information System (SIS) for Parties to provide information about how all safeguards, as referred to in the Cancun Agreement (appendix I), are being addressed and respected. Third, in 2013, UNFCCC COP 19 in Warsaw included the safeguards in the Warsaw Framework for REDD+. Finally, two years later, COP 21 in Paris (Decision 17/CP.21) referred to the need for further guidance when communicating how safeguards are being addressed and respected by REDD+ countries. The SIS will make countries eligible for result-based payments, based on reporting on the delivery of social and environmental safeguards.

Our conceptual framework consists of three parts. For the first part, namely our analysis of the character of the various safeguards, we use the following typology by Arhin (2014), which is more specific than other categorizations:

- Preventive safeguards - refer to 'doing no harm' to local communities.

- Mitigative safeguards - refer to minimizing the negative distributional impact of measures on local communities and their livelihoods.

- Promotive safeguards - refer to 'doing something better' to provide opportunities and spaces for forest-dependent communities to contribute to decision making, improve their livelihoods and benefit from the measures.

- Transformative safeguards - aim to pursue a radical shift in underlying assumptions and narratives to increase indigenous peoples' (IPs) and communities' access to and control of benefits.

The second part of our conceptual framework was developed based on the following bodies of literature that analyse key social issues and risks in the context of natural resource governance, including decentralization reforms, payment for ecosystem services (PES) and community-based conservation (e.g. Awono et al., 2013; Blom et al., 2010; Chhatre et al., 2012; Chomba et al., 2016; Dunlop \& Corbera, 2016; Hayes \& Persha, 2010; Sunderlin et al., 2014). The following are the most prominent social risks and concerns associated with the implementation of forest policies: (i) tenure insecurity (Awono et al., 2013; Cerbu, Sonwa, \& Pokorny, 2013; Hajjar, 2014; Mbatu, 2015; Nkemnyi et al., 2016; Sunderlin et al., 2014; Willis et al., 2016), (ii) inadequate avenues for local participation (Awono et al., 2013; Lawlor et al., 2013; Lesniewska \& McDermott, 2014; Wodschow et al., 2016), (iii) inequitable benefit sharing (Cerbu et al., 2013; Lawlor et al., 2013; Lesniewska and McDermott, 2014; Mbatu, 2015; Sunderlin et al., 2014) and (iv) adverse impacts on local livelihoods (Eba'a Atyi et al., 2013; Lesniewska \& McDermott, 2014; van Heeswijk \& Turnhout, 2013; Wiersum \& Elands, 2013). 
Furthermore, based on the works of one of the authors of this paper (Fobissie et al., 2012; Fobissie, 2014), which focus on forest governance and social safeguards in Cameroon - we introduced an additional, important aspect to be considered in the context of social safeguards in REDD+: free, prior and informed consent (FPIC). Building on these literatures, we distilled the following core aspects of social safeguards:

- Free, prior and informed consent (FPIC) and participation: FPIC lays down the principle to secure the full and effective participation of IPs and communities prior to any proposed interventions (e.g. a REDD+ project). Participation was analysed using Arnstein's (1969) ladder of participation, differentiating between manipulative, passive, functional, interactive participation, participation by consultation, participation for materials incentives and self-mobilization.

- Forest and land tenure: Tenure was analysed using the concept of 'bundle of rights', which includes access, withdrawal, management, exclusion and alienation rights (for detailed definitions of these rights, see Schlager \& Ostrom (1992).

- Social benefits and benefit sharing mechanisms (BSMs), including the impacts on local livelihoods: For BSMs, we applied the analytical parameters defined by Fobissie et al. (2014) and Lindhjem et al. (2011), who identified two dimensions of a benefit sharing arrangement: the vertical distribution of benefits between national and local stakeholders, and the horizontal sharing of benefits between and within a community. BSMs should be tailored to local conditions and needs and fulfil effectiveness, efficiency and equity criteria (see Assembe-mvondo et al., 2015; Chomba et al., 2016).

The third part of our framework focuses on monitoring and reporting commitments. A safeguard system requires a verifiable compliance component to ensure its effectiveness. The compliance component of a safeguard system could include effective monitoring and reporting systems, dispute resolution mechanisms and non-compliance mechanisms. In this study, we paid particular attention to and compared the monitoring and reporting obligations under the FLEGT-VPA and REDD+ processes. The monitoring and reporting system is basically meant to provide information about how the safeguards are being addressed and respected.

\section{Research design: case study and methods}

\subsection{Introducing the case study: The Cameroonian VPA and REDD+ processes}

Cameroon is renowned for its biodiversity and $42 \%$ of the country is covered by forest (COMIFAC, 2013). However, the country is facing an increased rate of deforestation and forest degradation, and recent studies have reported that it will soon experience even higher rates of deforestation (Tegegne et al., 2016). Cameroon is currently engaged in both the EU FLEGTVPA and REDD+. The processes are managed by two ministries: the Ministry of Forests (MINFOF) leads the VPA process, and the Ministry of Environment (MINEPDED) is responsible for overseeing the REDD+ process. The VPA between Cameroon and the EU was signed in October 2010 and ratified into Cameroonian law in August 2011. Several institutes have been set up to negotiate and implement the VPA process. The Joint Implementation Council (JIC) 
was created to oversee the VPA implementation, and is composed of two bodies: Committe Conjoint de Suivi (CCS) and the Council. The parties to the agreement decide who should participate in CCS meetings. Cameroon has included civil society organizations (CSOs) and indigenous peoples (IPS) and communities in recent CCS meetings. To guide and assess the implementation of the VPA, Cameroon established a National Monitoring Committee (NMC). This NMC has a fixed membership comprising representatives of the Prime Minister's office, the National Assembly, five government ministries, CSOs, IPs, the private sector and people who depend on communal forests. Cameroon has been in the implementation phase of the VPA process since 2011; that is, it is developing a Timber Legality Assurance System (TLAS) and methods of impact monitoring, and implementing transparency commitments.

Concerning the country's involvement in and efforts to benefit from REDD+, Cameroon has been engaged in two main REDD+ initiatives: the FCPF (since September 2010) and the UNREDD Programme (since November 2011), with the FCPF playing the main role in the national REDD+ Readiness process. Cameroon's Readiness Plan Idea Note (R-PIN) was validated in 2008 and the national REDD+ Readiness Plan (R-PP) was approved by the policy board of FCPF in 2013. Several institutes have been designed to follow up on the development and implementation of the country's REDD+ strategy. The REDD+ steering committee (the decision making body for the REDD+ process) consists of 19 members, namely 14 representatives from the government, one from CSOs, one from IPs and one from the private sector, and two representatives elected by MINNEPED. The Technical Secretariat is the operational body of the REDD+ process. It is composed of the UNFCCC focal point, the National REDD+ coordinator and a representative from the MINFOF. At the time of this research, Cameroon was in the readiness phase of the REDD+ process, that is, it was assessing drivers of deforestation, working on capacity building, and elaborating the national REDD+ strategy and Emission Reduction Program Idea Note (ER-PIN).

Several REDD+ projects and REDD+ related PES projects in Cameroon are at the development or implementation stage. These projects offer on-the-ground platforms for testing and learning activities that can be used to inform the design and implementation of national-level REDD+ actions. After discussions with the proponents of various REDD+ and PES projects, we decided to focus on two of the most advanced forest carbon PES projects, namely the Community PES and Ngoyla-Mintom REDD+ projects. Both projects were developed in accordance with the pro-community Plan Vivo system and standard for avoiding deforestation and forest degradation. They were also implemented within the framework of community forestry, designated by the 1994 forestry law of Cameroon. One of the projects was developed by the Centre for Environment and Development (CED) and Bioclimate, and implemented in two community forests: Nkolenyeng Community forest (which is dominated by Baka indigenous peoples) in the east, and Nomedjoh Community Forest (which is dominated by Bantu-Fang farming peoples) in the south (Figure 1). The second project (Ngoyla-Mintom REDD+ project) was funded by the European Union and implemented by WWF Cameroon in four community forests dominated by Bantu peoples in the south of 
Cameroon. The general forest types at the two project sites are mixed evergreen and deciduous humid forests. However, the forests are under serious pressure due to numerous mining explorations, the development of the cross-border railway between Cameroon, Gabon and the Republic of Congo, industrial logging, and immigration linked to these economic activities (Willis et al., 2016). In this context of economic development, securing the full rights of indigenous peoples and local communities to have complete access to the forests and to subsistence farming is a major challenge.

[Figure 1 about here]

\subsection{Methods}

The data collection for this study was carried out following a three-step approach. First, an extensive review of scientific and grey literature was undertaken, including official and policy documents related to FLEGT-VPA, REDD+ and safeguard approaches. An overview of the key policy documents reviewed is presented in Table 1 . The literature review and document analysis were also used to develop questions for the subsequent steps, namely an interview survey and a protocol for focus group discussions.

Second, semi-structured expert interviews were conducted by the first author during a threemonth stay in Cameroon in late 2015. Semi-structured interviews are suitable for gathering qualitative information about, for example, stakeholders' perceptions of processes. The interviewees were selected from various types of organizations using purposeful sampling techniques (see Table 2). The interviews were conducted face-to-face and were intended to capture different aspects of social safeguards, as distilled from the conceptual framework. Each of the 35 interviews lasted for about 1 hour and was recorded with the consent of the interviewee. In addition, two Skype interviews were conducted in February and March 2016 with important experts who had been abroad during the fieldwork. A standard list of questions was applied consistently to all interviewees. All questions were open-ended to allow the interviewees to express their personal experiences and perceptions of important issues identified during the review of literature and policy documents, and follow-up questions were asked for elaboration. Expert interviews were transcribed and analysed for content. In addition, when common trends and responses emerged, they were analysed through descriptive statistics to determine the numbers and percentages of the interviewees sharing any given views and opinions.

Third, six focus group discussions (FGDs) with indigenous peoples (IPs) and local communities participating in forest carbon PES projects were conducted. Table 3 summarizes the basic characteristics of the six sampled intervention villages at the project sites. The aim of the FGDs was to capture IPs' and local communities' expectations regarding FPIC and participation in the PES projects, tenure arrangements and BSMs. FGD participants were purposefully selected (Bedford and Burgess, 2001). The groups comprised village elders, village chiefs, representatives from the forest entity, and women, men and youth groups in the community. The discussions were transcribed and analysed for content. 
273 Table 1. Overview of key policy documents reviewed.

\begin{tabular}{|c|c|c|c|}
\hline Document title & Prepared by & $\begin{array}{l}\text { Publication } \\
\text { year }\end{array}$ & Reference \\
\hline $\begin{array}{l}\text { Forest Law Enforcement, Governance and Trade (FLEGT): } \\
\text { Proposal for an Action Plan }\end{array}$ & European Commission & 2003 & $\begin{array}{l}\text { European Commission, } \\
2003\end{array}$ \\
\hline $\begin{array}{l}\text { FLEGT briefing notes: Forest Law Enforcement, Governance } \\
\text { and Trade }\end{array}$ & European Commission & 2007 & $\begin{array}{l}\text { European Commission, } \\
2007\end{array}$ \\
\hline $\begin{array}{l}\text { FLEGT Voluntary Partnership Agreement between Cameroon } \\
\text { and the European Union }\end{array}$ & $\begin{array}{l}\text { European Commission and } \\
\text { Cameroon }\end{array}$ & 2010 & Cameroon VPA, 2010 \\
\hline $\begin{array}{l}\text { Guidelines for developing legality definitions in FLEGT } \\
\text { Voluntary Partnership Agreements }\end{array}$ & European Forest Institute & 2012 & $\mathrm{EFI}, 2012$ \\
\hline REDD+ Readiness Preparation Proposal Cameroon & $\begin{array}{l}\text { Ministry of the Environment, the } \\
\text { Nature Protection and } \\
\text { Sustainable Development } \\
\text { (Cameroon) }\end{array}$ & 2013 & MINEPDED, 2013 \\
\hline $\begin{array}{l}\text { Operational Guidelines for Obtaining Free, Prior and } \\
\text { Informed Consent in REDD+ Initiatives in Cameroon Including } \\
\text { Principles, Criteria and Indicators. }\end{array}$ & $\begin{array}{l}\text { Ministry of Environment, Nature } \\
\text { Protection and Sustainable } \\
\text { Development (Cameroon) } \\
\end{array}$ & 2015 & MINEPDED, $2015 a$ \\
\hline The World Bank Operations Manual & World Bank & 2005 & World Bank, 2005 \\
\hline Guidelines on Stakeholder Engagement & World Bank and UN-REDD & 2012 & FCPF UNREDD, 2012 \\
\hline Readiness Preparation Proposal (R-PP) & FCPF & 2010 & FCPF UNREDD, 2010 \\
\hline $\begin{array}{l}\text { Guidelines and Generic Terms of Reference (ToR) for an } \\
\text { SESAs and ESMF }\end{array}$ & FCPF & 2010 & FCPF, 2010 \\
\hline UNFCCC Cancun agreement & UNFCCC & 2011 & UNFCCC, 2011 \\
\hline Cameroon ER-PIN draft document & MINEPDED & 2015 & MINEPDED, 2015b \\
\hline
\end{tabular}




\begin{tabular}{|l|l|l|}
\hline Categories of interviewees & Organizations & $\begin{array}{l}\text { Number } \\
\text { interviewed }\end{array}$ \\
\hline National governmental organizations & $\begin{array}{l}\text { Ministry of Forests (MINFOF); Ministry of the Environment, the Protection of } \\
\text { Nature and Sustainable Development (MINEPDED) }\end{array}$ & 10 \\
\hline $\begin{array}{l}\text { International organizations } \\
\text { (governmental and non-governmental) }\end{array}$ & $\begin{array}{l}\text { Center for International Forestry Research (CIFOR); Deutsche Gesellschaft für } \\
\text { Internationale Zusammenarbeit (GIZ); World Bank; World Wide Fund for } \\
\text { nature; International Union for Conservation of Nature; Wildlife Conservation } \\
\text { Society; Environmental Investigation Agency }\end{array}$ & 11 \\
\hline National Civil society organizations & $\begin{array}{l}\text { National REDD+ and Climate Change Platform; Centre for Environment and } \\
\text { Development (CED); Centre for Assistance to Justice and Animation for } \\
\text { Development (CAJAD); Forest and Rural Development (FODER); Fondation } \\
\text { Camerounaise Terre Vivante (FCTV) }\end{array}$ & 14 \\
\hline National academic institutes & University of Yaoundé I; University of Dschang & 2 \\
\hline
\end{tabular}

Table 3. Basic characteristics of the six sampled villages in project sites.

\begin{tabular}{|l|l|l|l|l|l|l|}
\hline & \multicolumn{2}{|c|}{ PES project ${ }^{1}$} & \multicolumn{4}{c|}{ REDD+ Ngoyla-Mintom Project $^{2}$} \\
\hline Village & Nomendjoh & Nkolenyeng & Etekessang & Zoulabot & Messok-Messok & Ndimako \\
\hline Total inhabitants & 896 & 555 & 212 & 198 & 147 & 186 \\
\hline Ethnic groups & Mainly Baka & Bantu (92\%), Baka (8\%) & Bantu only & Bantu only & Bantu only & Baka only \\
\hline Total forest area & 1942 ha & 1042 ha & 3135 ha & 3254 ha & 1480 ha & -3 \\
\hline $\begin{array}{l}\text { Main economic } \\
\text { activities }\end{array}$ & $\begin{array}{l}\text { Agriculture labour } \\
\text { in Bantu fields, } \\
\text { Hunting, gathering } \\
\text { NTFPs }\end{array}$ & $\begin{array}{l}\text { Bantu: Agriculture, logging, } \\
\text { gathering NTFPs. } \\
\text { Baka: Agriculture labour in } \\
\text { Bantu fields, Hunting, } \\
\text { gathering NTFPs }\end{array}$ & & $\begin{array}{l}\text { Hunting, } \\
\text { agriculture labour } \\
\text { in Bantu fields, } \\
\text { gathering NTFPs }\end{array}$ \\
\hline
\end{tabular}


Drivers of forest Expansion of food and cash crops such as plantain, cassava and peanut. Timber exploitation, unsustainable exploitation of loss non-timber forest products (NTFPs)

$279{ }^{1}$ National NGO - CED - is the leading proponent

$280{ }^{2}$ WWF lead the REDD+ Ngoyla-Mintom project

$281{ }^{3}$ Ndimako is part of the community forestry of Etekessang 
The results are presented in three sections: (1) proposed social safeguards under the FLEGTVPA and REDD+; (2) monitoring and reporting requirements; and (3) similarities and differences between the safeguards of FLEGT-VPA and REDD+.

\subsection{Social safeguards under FLEGT-VPA and REDD+} The FLEGT Action Plan, VPA text (including its annexes) and implementing guidelines are very brief when it comes to the definition, scope and objectives of social safeguards. The European Commission (2007) states that key elements to consider in designing and implementing a VPA are likely to include social safeguards, to minimize adverse impacts on local communities. It is this aspect that has been adopted in the majority of negotiated VPAs, including that of Cameroon (see Cameroon VPA, 2010, Art. 17). The concept of social safeguards is not further elaborated in any of the 11 annexes of the Cameroonian VPA. However, the need to consider livelihoods is reiterated in several articles (see Cameroon VPA, 2010, Art. 2; 15 and 16). Furthermore, the legality definition is another part of the VPA where safeguards are highlighted (EFI, 2012). Cameroon's legality definition is framed around five criteria, including social obligations such as compliance with employment, social security and labour laws and social agreements.

Cameroon is an active member of the World Bank's FCPF programme and its R-PP outlines the procedures for the development of Strategic Environmental and Social Assessment (SESA) (FCPF, 2010), and adopts preventive and mitigative safeguards. As stated in the R-PP (MINEPDED, 2013, p. 83) the SESA 'is the approach that allows Cameroon to reduce as much as possible or to eliminate the possible social and environmental impacts [...] during the design and implementation of the REDD+ strategy or to offset them.' The R-PP discusses fundamental questions, such as participation, BSMs and tenure. However, the R-PP does not clearly describe how SESA will be implemented, and it states that SESA will be based in part on the criteria and indicators of the VPA (MINEPDED, 2013, p. 86). Table 4 compares and summarizes the core aspects of social safeguards of the FLEGT-VPA and REDD+ processes. 
Table 4. Comparative analysis of the social safeguards of FLEGT-VPA and REDD+ in Cameroon

\begin{tabular}{|c|c|c|}
\hline $\begin{array}{l}\text { Aspects of } \\
\text { social } \\
\text { safeguards }\end{array}$ & FLEGT-VPA & REDD+ \\
\hline FPIC & $\begin{array}{l}\text { VPA text makes no reference to FPIC } \\
\text { Indeginous peoples and communities } \\
\text { have a pre-emptive right to refuse } \\
\text { allocation and claim their rights. }\end{array}$ & $\begin{array}{l}\text { Adopted and validated FPIC guidelines } \\
\text { FPIC requirements have not been met } \\
\text { in the field }\end{array}$ \\
\hline $\begin{array}{l}\text { Participation of } \\
\text { IPs and } \\
\text { communities }\end{array}$ & $\begin{array}{l}\text { Requires 'consultation' rather than } \\
\text { 'participation', which does not by itself } \\
\text { ensure full and effective participation } \\
\text { The CCS }{ }^{1} \text { has included IPs and } \\
\text { communities in recent meetings }\end{array}$ & $\begin{array}{l}\text { Consultation is the defining form of } \\
\text { participation } \\
\text { Consultation of indigenous and local } \\
\text { communities is a right }\end{array}$ \\
\hline $\begin{array}{l}\text { Land and forest } \\
\text { tenure }\end{array}$ & $\begin{array}{l}\text { Promotes recognition of access or use } \\
\text { rights; does not extend to full ownership } \\
\text { rights for IPs and communities } \\
\text { There is no mention of IPs and } \\
\text { communities }\end{array}$ & $\begin{array}{l}\text { Recognizes user and access rights, but } \\
\text { not full ownership } \\
\text { Recognizes the conflicts between state } \\
\text { and customary right, but does not } \\
\text { provide any guidance }\end{array}$ \\
\hline $\begin{array}{lr}\text { Social benefits } \\
\text { and } \\
\text { sharing }\end{array}$ & $\begin{array}{l}\text { Acknowledges the need for vertical } \\
\text { benefit sharing but provides no guidance } \\
\text { Recognizes the need to consider the } \\
\text { livelihoods of IPs and communities }\end{array}$ & $\begin{array}{l}\text { Plan to develop vertical and horizontal } \\
\text { benefit sharing mechanisms } \\
\text { The planned benefit sharing } \\
\text { mechanism will have effectiveness, } \\
\text { efficiency and equity problems }\end{array}$ \\
\hline $\begin{array}{l}\text { Monitoring and } \\
\text { reporting } \\
\text { commitments }\end{array}$ & $\begin{array}{l}\text { VPA has a legally-binding commitment to } \\
\text { monitor and report } \\
\text { VPA plans to meet the reporting } \\
\text { obligations by making the monitoring } \\
\text { reports available online }\end{array}$ & $\begin{array}{l}\text { The R-PP makes provisions for the } \\
\text { monitoring and reporting of social } \\
\text { safeguards through } \\
\text { institutionalization of SESA }\end{array}$ \\
\hline
\end{tabular}

${ }^{1}$ CCS (Committé Conjoint de Suivi) is one of the two bodies of Joint Implementation Council of the VPA process in Cameroon.

\subsubsection{FPIC and participation}

315 The full and effective participation of relevant stakeholders, including indigenous peoples

316 (IPs) and local communities, is essential for achieving effective and sustainable 317 implementation of FLEGT-VPA (Wodschow et al., 2016) and REDD+ (FCPF-UNREDD, 2012). All

318 stakeholders involved in, affected by or interested in the processes should actively engage at 319 all level of the processes. 'In order for REDD+ and FLEGT to achieve their policy goals, the 320 processes should have long-term planning and monitoring to ensure active participation of IPS and local communities, who have an important role to play in sustainable management of natural resources' noted an interviewee. The VPA text states that IPs and communities will be regularly consulted on the implementation of the VPA through the NMC (Cameroon VPA, 2010, Annex III $(a, b))$. Nonetheless, the VPA fails to specify the roles and powers of IPs and communities in decision making and the implementation of the VPA process. Sixty per cent of interviewees, mainly from CSOs, interpreted the use of the word 'consult' in the VPA text to mean that only a weak level of non-state actors' involvement in the VPA process is 
required. This could also imply that consultation is the defining form of participation during VPA implementation in Cameroon, and hence not as many steps up Arnstein's (1969) ladder as it could be. An interviewee from a national CSO stated that 'what we are witnessing in Cameroon's forest sector is the decreasing opportunities for multi-stakeholder participation and an increasing influence of the state in the implementation of FLEGT-VPA and REDD+'. This contradicts the expectation of IPs and communities. We found across the six FGDs that IPs and communities would like to have a partnership form of participation (in FLEGT-VPA and REDD+ processes) that enables them to negotiate and engage in trade-offs with project proponents and the government.

The Cameroon REDD+ policy documents provide non-state actors with an opportunity to participate in decision making. However, a closer look at the current composition of the REDD+ steering committee revealed the weak representation of CSOs and IPs during decision making. Representatives from CSOs, IPs, the private sector and elected representatives make up only a quarter of the members of the steering committee, whereas decision making by the committee is done through a majority vote (two thirds of the members), at the expense of consensus (MINEPDED, 2013). As noted by the majority of interviewees (75\%) and FGDs, this offers non-state actors only a very slim chance of making their concerns heard, implying that consultation is the defining form of participation during REDD+ implementation in Cameroon. Such decision making may not help Cameroon to fully and easily address the Cancun safeguards requirements and adhere to the FCPF and UN-REDD joint guidelines on the participation of stakeholders (FCPF-UNREDD, 2012), which require the full and effective involvement of IPs and communities.

Although the VPA process does not specifically require FPIC during the allocation of forest concessions, in 2014 the Cameroon government elaborated and validated a national REDD+ FPIC guideline document (MINEPDED, 2014). Thirty out of 37 interviewees $(80 \%)$ and participants in the FDGs stated that although the FPIC guide is a step towards the effective attainment of decision making power by IPs and communities, its implementation remains an important challenge. For instance, in 2015 the government failed to comply with its own REDD+ FPIC principles during the preparation of the Cameroon ER-PIN. This assertion corroborates similar findings by Carodenuto \& Fobissie (2015). During the fieldwork it was observed that the requirement that FPIC should be obtained had not been met in the two projects examined in this study. 'Most of the meetings during the project design did not take our traditional calendar into account and the meetings were not conducted in our indigenous Baka language. The project proponents also failed to provide us with relevant information in advance' (an FGD participant in Ndimako village). That said, our analysis shows that consultation is the most dominant form of participation in the design and implementation of safeguard systems of FLEGT-VPA and REDD+ in Cameroon.

\subsubsection{Land and forest tenure}

Clarifying land and forest tenure is crucial to identifying natural resource rights holders, who should thus participate in decision making processes, and those who are entitled to receive 
FLEGT-VPA and REDD+ benefits. Tenure basically refers to the relationships, systems and rules that determine rights to land and forest resources. Tenure rights can range from use right to exclusion and alienation rights. Their position in the spectrum of tenure rights can greatly affect the ability and motivation of IPs and local communities to manage natural resources sustainably. In this light, the Cameroon VPA makes explicit mention of the need to recognize and respect customary rights (see Cameroon VPA, 2010, Annex VIII). However, such recognition is mostly limited to access or use rights, and does not extend to full ownership rights for IPs and communities. This is because during the VPA negotiation there was an assumption among Cameroonian stakeholders that the basis of the VPA would be in conformity with existing national legislation, which at the time did not provide for ownership rights. It was therefore difficult for non-state actors to advocate for and have full ownership in the VPA text. Furthermore, 21 out of 37 interviewees (55\%) and participants in the FGDs asserted that the Cameroon VPA and REDD+ processes lack clear procedures for securing land and forest tenure for IPs and communities.

The Cancan Agreement acknowledge the importance of tenure issues but there is no further elaboration, referring only to national laws and sovereignty (See UNFCCC, 2011, Art. 72). The Cameroon R-PP (MINEPDED, 2013, p. 47) also highlights tenure insecurity as a concern and acknowledges the conflicts between customary and formal law. The R-PP (p. 45) states that 'the [country's] law governing land issues are clear: the laws take precedence over customary right'. The R-PP mainly refers to 1974 land tenure and 1994 forestry laws, which do not recognize customary rights to forest and land, and limit IPs and communities' rights to user and access rights (Alemagi \& Kozak, 2010; Assembe-Mvondo et al., 2014). Moreover, both land and forestry laws attribute the ownership of valuable forest resources to the state (Mbatu, 2015) and do not specify whether carbon ownership is associated with rights over trees. Thus, a significant amount of the country's forest carbon is state-owned. To address the given inadequacies, the R-PP (MINEPDED, 2013, p. 63) proposes the development of a national land-use plan and improvements to the existing land tenure law. Finally, whilst the VPA and REDD+ processes aim for the recognition of access or use rights, the FGDs in six villages revealed that IPs and communities would like to have, in addition to access right, legal rights of management and exclusion, which are considered necessary to sustainably use natural resources (Schlager and Ostrom, 1992).

\subsubsection{Social benefits and benefit sharing}

The effectiveness of the FLEGT and REDD+ processes will depend on, for example, their ability to equitably distribute benefits to the relevant stakeholders (Chomba et al., 2016; Dunlop \& Corbera, 2016; Somorin et al., 2014). The benefits can be shared between national and local stakeholders (vertical distribution) and between and within a community (horizontal distribution). The Cameroonian VPA refers to benefit sharing mechanisms (BSMs) as a part of social obligations. A provision on how to develop a BSMs under the VPA is quite weak and is not further elaborated in the Cameroonian VPA. An interviewee from a governmental organization noted that 'Cameroon has a functioning forest revenue-distribution model 

forestry law and the same system will be adopted under the VPA process'. If adopted, this will imply that the VPA is primarily targeting the vertical distribution of benefits. Twenty-six out of 37 interviewees, mainly from CSOs and international organizations, expressed their fear that the VPA could reinforce the effectiveness, efficiency and equity problems inherent in AFR, which suffers from high transaction costs and has failed to achieve poverty reduction and local development (Assembe-mvondo et al., 2015; Mbatu, 2015). The same group of interviewees also said that although the implementation of the VPA itself will not bring new social benefits (e.g. make a contribution to local development) to IPs and communities, they stressed that the VPA could improve compliance with the law and the relationship between logging companies and the communities.

Like the VPA process, the REDD+ process has not yet developed BSMs although it does lay out some initial steps. The R-PP (MINEPDED, 2013, p. 76) presents two levels of payments: vertical and horizontal distribution of benefits. The R-PP (p. 76) proposes basing the BSMs on the experiences of other in-country revenue distribution models, notably AFR, which has contributed to the marginalization of IPs such as Baka forest peoples. In the same vein, the World Bank's FCPF requires that distributions of financial benefits from its Carbon Fund should occur in the context of a national BSMs, but exact arrangement are not specified (Cadman et al., 2016, p. 3). During all the FGDs, IPs and local communities blamed AFR for bureaucratic red tape and poor governance. A participant in FGDs in Ndimako noted that 'when AFR incentives reach our village, the incentives have often been mismanaged by local elite and traditional authorities. It is quite common for the incentives go to the Bantu farming peoples and not to Baka indigenous forest peoples'. This assertion corroborates similar findings by Freudenthal et al. (2011). Finally, MINEPDED (2013) identifies IPs and local communities as the primary beneficiaries of the REDD+ benefits, and also states that the participation of stakeholders in decision making is indispensable, but does not identify the form of participation. Thus, our analysis shows that the business-as-usual proposals for the BSMs under REDD+ and VPA processes in Cameroon will reinforce the injustices inherited in the AFR and existing legal systems. Unless this situation is rectified, IPs and local communities will have no motivation to actively engage in the processes.

4.2 Monitoring and reporting commitments on social safeguards To ensure that it can effectively comply with the international safeguard standards, and report that compliance, a country should assess the existing monitoring and reporting tools and procedures of other relevant processes and initiatives being implemented in the country. Understanding the different monitoring and reporting procedures could help countries identify common reporting guidelines, methodologies and best practices for gathering information and reporting on compliances (Korwin and Rey, 2015). Here, we assess and compare the monitoring and reporting obligations under the FLEGT-VPA and REDD+ processes. 
Under the VPA process, commitments to monitoring are more elaborate in comparison to commitments to reporting. The VPA impact monitoring framework (which is under development) will monitor the environmental, social and economic impacts of the VPA, and thus the social safeguards (Tegegne et al., 2014). The Cameroon VPA mandates the IIC to implement the legally-binding monitoring commitment and to undertake annual reporting on VPA impact monitoring, including that on social aspects. It is assumed that when they are available, the reports, documents and conclusions of the VPA impact monitoring will made public on the internet. Moreover, Cameroon is the first Central African country to have an independent forest monitor, whose roles include strengthening the monitoring capacities of MINFOF, improving existing monitoring tools and adapting the monitoring tools to the requirements of the FLEGT-VPA TLAS (Brack \& Léger, 2013, p.15). The VPA process recognizes a continuing role for the independent forest monitor, listing the 'independent observation' involving local civil society for monitoring and reporting on, inter alia, compliance with existing regulations, which is of relevance to REDD+.

The REDD+ policy documents refer to both the monitoring and the reporting of social safeguard related aspects. Cameroon's proposed solution to monitoring and reporting on social safeguards in its REDD+ process is through the development of SESA. However, there is insufficient detail about the criteria and indicators to be adopted in monitoring and reporting on social safeguards in REDD+ in the country. Rather, it is assumed that indicator frameworks for governance and social impacts developed in other national and international processes and/or projects will be used. In this context, a direct linkage is made to the criteria and indicators developed in the context of the FLEGT-VPA (MINEPDED, 2013).

\subsection{Similarities and differences between social safeguard approaches}

A comparison of the safeguard approaches of the FLEGT-VPA and REDD+ processes revealed important similarities. First, there is similarity in the nature of developing benefit sharing mechanisms, strengthening forest and land tenure, and monitoring and reporting. This is because both processes in Cameroon (i) promise to conduct a multi-stakeholder approach, (ii) rely on existing legal and institutional systems, and (iii) plan to develop criteria and indicator based monitoring and reporting frameworks. Second, both processes consider the preventive and mitigative roles of safeguards. Third, FLEGT-VPA and REDD+ share common social concerns. During the interviews, three important social risks and potential synergies were frequently mentioned, namely (in order of importance): i) strengthening the tenure rights of IPs and communities, ii) improving forest governance, including the reform of laws and stakeholder engagement, and iii) benefit sharing. However, the importance attached to social risks differed between the experts interviewed and the participants in the FGDs. The latter ranked social benefits and benefit sharing as the most important concern, followed by land and forest tenure and participation in decision making processes. Fourth, section 4.1 shows that both processes will lead to social safeguard mechanisms that are based on outdated national laws, which do not recognize customary rights and limit the active engagement of forest-dependent communities. The observed similarities in social safeguards 
can be attributed to the common origins of safeguards and the overlaps in the policy goals of FLEGT Action Plan, FCPF and UN-REDD, and the general trend and pressure from CSOs to emphasize similar issues in all processes. The similarities can also be attributed to recent trends in bilateral and multilateral policy processes to develop and use criteria and indicators for monitoring, reporting and verifying results and impacts.

Our analysis also revealed important differences. First, in REDD+, social safeguard compliance is a prerequisite for result-based incentives; under the VPA it is a legal obligation and linked to market access. Second, while the VPA mainly includes plans for the vertical distribution of benefits, REDD+ considers both vertical and horizontal sharing of benefits. Third, membership of IPs in the REDD+ steering committee is a right, which is not the case with the FLEGT-VPA process. Fourth, and perhaps most importantly, although neither the FLEGT Action Plan nor the VPA elaborates the details of social safeguards, several mechanisms and options are under consideration in the REDD+ safeguards framework. The differences uncovered can be attributed to the different designs and approaches of the two processes. Unlike REDD+, which is the result of a multilateral process, national and regional (EU) stakeholders define the scope of the VPA (see also Wodschow et al., 2016). During the VPA negotiations in Cameroon, stakeholders regarded the FLEGT-VPA as an agreement aimed at improving governance and alleviating poverty. In this context, and with a view to addressing the negative unintended effects that could arise, the article on social safeguards and commitment to VPA impact monitoring was included in the Cameroon VPA agreement. REDD+ is different, as actors tend to be concerned that it is not being developed to improve governance and reduce poverty, and so the focus is much more on including social safeguards.

\section{Discussion}

In this section, we discuss synergies in the social safeguards of FLEGT-VPA and REDD+, the main challenges to realizing the synergies, and the policy implications of the key findings of the study.

\subsection{Synergies}

Our analysis shows that although FLEGT and REDD+ originated in different environmental governance arenas, there are potential synergies between the social safeguard approaches of the processes. First, there is crucial synergy to be realized in the multi-stakeholder nature of developing benefit sharing mechanisms, strengthening forest and land tenure, and defining criteria and indicators in relation to FLEGT-VPA and REDD+ safeguards. Realizing these synergies will have the advantage of what Tegegne et al. (2014) and Ochieng et al. (2013) have referred to as 'transfer of commitments'. For instance, under the VPA, Cameroon committed itself to undertaking a reform of regulatory frameworks to harmonize existing laws with the TLAS requirements; under REDD+, the country committed itself to clarifying rights and mechanisms for sharing benefits. Thus, Cameroon can fulfil both commitments using the resources from only one of the processes. 
Second, FLEGT and REDD+ have features that could complement each other in addressing the gaps in the protection of IPs' and communities' rights and benefits. The Cameroon VPA promotes independent third-party monitoring and has been providing financial and technical support for the participation of civil society in reporting and monitoring (Brack and Léger, 2013). Hence, CSOs in Cameroon have been carrying out 'self-mandated' monitoring and reporting, identifying cases of illegal practices at the community level, and providing on-theground evidence that is crucial to ensuring the effective monitoring of forest governance and compliance with forest regulations. These experiences of CSOs could provide important lessons for the inclusion of civil society in the design and implementation of REDD+'s social safeguards and benefit sharing mechanisms. All these will go a long way to providing the country's safeguards systems with legitimacy, effectiveness and credibility.

Third, the development of a legality definition in the context of the VPA includes a comprehensive gap analysis of relevant national polices, laws and regulations. The results of this assessment will be useful when developing the safeguard information system (SIS) for REDD+.

Fourth, the VPA's transparency annex lays out the government's promise to make public information that is of relevance to the monitoring and reporting of REDD+ safeguards and the 'informed' principle of FPIC. In this context, one of the CSOs, FODER, is drawing on its FLEGT experience from the Championing Forest People's Rights and Participation (EU-CFPR) project to initiate discussions and propose the development of the REDD+ transparency guide in Cameroon. In addition, REDD+'s FPIC guideline could be used by VPA actors when engaging with stakeholders and allocating forest concessions.

Finally, there are synergies between monitoring and reporting tools and procedures, as well as gathering baseline information on compliance (see also Ochieng et al., 2013). A crucial purpose of VPA impact monitoring is to assess and report changes related to such topics as the effective engagement of stakeholders, tenure and rights, and distribution of benefits (Tegegne et al., 2014). VPA's TLAS also include several requirements for monitoring and reporting on-the-ground legal compliance, independent third-party monitoring and companies' social obligations. Much of this information is particularly relevant for REDD+ SIS.

\subsection{Challenges to realizing the synergies}

Despite the potential synergies, our analysis points to several challenges to realizing them. The first challenge is the lack of domestic political will in Cameroon to devote resources and efforts to the synergetic implementation of FLEGT-VPA and REDD+ policies (see also Karsenty \& Ongolo, 2012). The lack of political interest can partly be explained by the recent shift in Cameroon's vision and political priorities towards becoming an emerging economy by 2035. This vision pays little attention to environmental sustainability and entails, amongst other things, the development of large-scale agriculture, investments in infrastructure and the mining of minerals such as cobalt, diamonds, gold and iron ore. These developments imply a 
decreasing importance of the EU timber market and the growing trade with Asia (Wodschow et al., 2016).

The second challenge is the complex vested interest of political and economic elites in the country's existing governance system. 'Those who have interest in the existing system are those who are governing the system, so they would like to keep the status quo of contradictory policy implementation and thus preserve scope for personal agendas' noted an interviewee from an international organization. This sentiment echoes recent research on the topic: Carodenuto and Cerutti (2014), Foundjem-Tita et al. (2014), Nkemnyi et al. (2016)and Ongolo (2015) observed that elites in Cameroon have a strong interest in maintaining an incoherent and uncoordinated status quo. Given these interests, seeking synergies between the safeguard systems of FLEGT and REDD+ and any legal reforms in Cameroon seem unlikely. In the same vein, any possible changes and reforms will likely not be useful in securing the rights of IPs and local communities without addressing how the system favours the vested interests. This limits the democratic space of IPs and local communities to exert influence on the final outcomes of the policy processes. Vested interest is also a common obstacle to realizing synergies in other countries participating in both FLEGT-VPA and REDD+ processes, such as Ghana (Hajjar, 2015), Republic of Congo (Tegegne, 2016) and Indonesia (Brockhaus et al., 2014).

The third challenge is the lack of coordination - accompanied by conflicting interests between and within governmental agencies, national CSOs as well as global proponents and donors of FLEGT and REDD+. Among governmental agencies, a crucial obstacle is the conflicting leadership between the two implementing ministries: MINEPDED (overseeing the country's REDD+ process) and MINFOF (the main custodian of the country's forests). This conflictual leadership calls into question the capacity of the VPA and REDD+ processes to operate effectively and serve as levers for safeguarding the right of IPs and communities. At the international (and also the national) level, FLEGT and REDD+ are two separate processes under two disconnected proponents (e.g. the UNFCCC and the World Bank versus the EU). Relevant policy documents of the global proponents lack cross-referencing on related instruments of the processes. For example, as noted by an interviewee: 'REDD+ actors in Cameroon have focused on developing an MRV system. MRV is being constructed as a system completely separated from the FLEGT-VPA'S TLAS and according to general criteria provided by the World Bank, which do not make any link to the FLEGT-VPA TLAS.' In addition, the synergy approach to policy processes is itself an emerging issue even at the international level, and it has not yet found its way into national and subnational policies and strategies (Duguma et al, 2014). Interviews support this viewpoint. 'Seeking synergies between FLEGT and REDD+ is very much an internationally driven agenda (in particular by the EU)' stated an interviewee from a governmental organization. A further challenge is 'strong division and conflicts among national CSOs and intra-community between those favouring conservation or conversion' noted an interviewee from CSOs. This sentiment corroborates similar findings by Ongolo (2015), Alemagi and Kozak (2010) and Wodschow et al. (2016). Such competition 
hampers the ability of non-state actors and hinders collective action to influence the policy elites and advocate for coherent policy implementation.

A fourth challenge is the lack of technical knowledge and information about the safeguards of FLEGT-VPA and REDD+ among stakeholder groups. Cameroon, just like many other countries, is yet to generate adequate data and information to inform and report on the development and implementation of a national SIS. Finally, there is no defined financial mechanism for efforts promoting and implementing synergies at the subnational, national and global levels. This may lead to a situation in which those involved will see it as a waste of time, limiting their chances to get separate and more funding and not serving their personal interest or that of their institution.

\subsection{Policy implications}

First, while country safeguard systems should build on existing governance arrangements to respond effectively to safeguards commitments in a rigorous yet flexible manner, our analysis shows otherwise in Cameroon. The existing national policies, laws and regulations have several weaknesses and are not supporting Cameroon in fully addressing the safeguard requirements of UNFCCC, FCPF and UN-REDD. Cameroon has historically been characterized by inefficient and weak governance institutions (Mbatu, 2015). In this light, we argue that without effective dialogue and the reforms needed to meet the required social safeguard commitments, there is a real danger that investments of UN-REDD, the World Bank and the EU through the REDD+ and VPA processes will serve to reinforce outdated regulatory frameworks and could even result in human rights violations during REDD+ implementation. It is therefore crucial that the ministries involved, REDD+ proponents, communities, CSOs, and international organizations and donors take appropriate steps to ensure that relevant legislative and subnational and project-based actions are taken to reduce any potential negative consequences.

Second, considering the current approaches to governance and legality, neither FLEGT-VPA nor REDD+ will effectively address the key social concerns identified in this study: inefficient stakeholder engagement, tenure insecurity and inequitable sharing of benefits. One of the weaknesses of the FLEGT-VPA is that it bases its design on existing regulatory frameworks, which is vital for national ownership and legitimacy (Lesniewska and McDermott, 2014; Wiersum and Elands, 2013). According to van Heeswijk \& Turnhout (2013), FLEGT is shaped by state-oriented discourses that promote existing regulatory instruments that may not necessarily promote sustainability and effective participation. In practice, however, this approach has so far not worked well in Cameroon. An example is Cameroon's forestry and land tenure laws, which aggravate the conflicts between customary and formal law (Mbatu, 2015; Nkemnyi et al., 2016). Alemagi \& Kozak (2010, p. 558) also noted that the existing regulatory frameworks in Cameroon have served to 'usurp property rights of forest communities'. It is interesting to observe that REDD+ (whose design is not based on existing national law) has not provided strong provisions to resolve problems associated with land tenure and, more interestingly, has not discussed forest carbon rights, which appear to be 
attributed to the state. The results of case studies in Cameroon also indicate that resolving tenure insecurity under REDD+ and the current political economy of the country will prove difficult (Cerbu et al., 2013; Nkemnyi et al., 2016; Sunderlin et al., 2014). During the six FGDs in south and east Cameroon, IPs and local communities showed concern about tenure insecurity and pointed out that addressing the tenure problem will be a challenging task. This is because, for example, 'the existing tenure arrangement gives privileged access to forest resources to powerful elites' (an FGD participant in Nomedjoh village). Assessing the effectiveness of Cameroon's REDD+ policy strategy, Mbatu (2015, p. 54) states that "access and tenure in Cameroon's forests have been an issue of confrontation between the government of Cameroon and its peoples for decades". The unresolved uncertainty about land tenure and ownership rights could erode the legitimacy of FLEGT and REDD+, and cast a shadow of doubt over the rights of IPs and local communities to carbon ownership and their active participation in the processes. Our analysis supports similar findings by Cerbu et al. (2013), Hajjar (2015) and Movuh (2012), who concluded that without effective and inclusive reform of tenure law and a change in incentive structures, FLEGT-VPA and REDD+ processes are not likely to succeed.

Third, the two main tools providing guidance for the development of safeguards in the Congo Basin (FCPF and UN-REDD) require that the rights and needs of IPs and local communities be met to ensure the sustainable success of FLEGT and REDD+. Nonetheless, there is an important discrepancy between the needs of forest-dependent communities and the proposed safeguard approaches (Table 4). During the fieldwork, IPs and communities explicitly mentioned the need to have management and exclusion rights and a mechanism for the equitable sharing of benefits. They would also like to be grantor of FPIC and have promotive safeguards in addition to the preventive and mitigative safeguards planned in the policy documents of FLEGT and REDD+. As discussed in section 4.1, none of these needs and expectations of IPs will be effectively addressed and respected during FLEGT and REDD+ implementation in Cameroon if the processes continue with the proposed plan for designing and implementing safeguard systems.

Fourth, building a robust and flexible safeguard system that address the abovementioned concerns will need careful thinking and planning that integrates multiple objectives, at both the national and the international level. At the national level, policies and their interplay across the ministries in charge of forests (MINFOF), REDD+ (MINEPDED), indigenous peoples (MINAS) and regional planning (MINEPAT) will need to be considered. We argue that a national safeguard system in Cameroon and other Congo Basin countries, such as the Republic of Congo, Central African Republic and Democratic Republic of Congo, which are all engaged in FLEGT, could build on subnational level experiences related to FLEGT and REDD+. A unique opportunity is the emissions reduction program (ERP), which in some cases, like in Cameroon, is focused on areas where logging and the FLEGT process are happening. In practice, this means that both FLEGT and ERP issues affecting communities should be addressed. This 
includes land use planning, consultation and participation, benefit sharing arrangements, and respecting the rights of communities and indigenous peoples.

At the international level, Cameroon and other countries are expected to use data and knowledge generated from the ERP, other REDD+ and FLEGT activities to design and develop a comprehensive national SIS, inform safeguard-related issues and policies over time, and report to the UNFCCC and EU how safeguards are being implemented and respected. This implies that the governments of Cameroon and other developing countries are expected to design ERPs that have a strong safeguard component that meets or exceeds the requirements of not only World Bank safeguard standards but also the UNFCCC Cancun decisions on safeguards, as well as safeguards issues linked to FLEGT. Otherwise, Cameroon, just like any other country engaged in REDD+, will not be able to access REDD+ result-based financing easily at the international level. With the discouraging carbon price in the carbon market, coupled with an excessive supply of REDD+ credits and limited financing from the markets and donors, REDD+ credits that have strong safeguards credentials may become more attractive for buyers and donors. Furthermore, UNFCCC negotiations and subsequent decisions on safeguards during COP in Warsaw (2013) and Paris (2015) sent a clear signal from developed countries to developing countries that the implementation and respect of safeguards remain a top priority and prerequisite for REDD+ payments.

\section{Conclusions}

This paper has presented a comparison of the social safeguard approaches of the FLEGT-VPA and REDD+ processes and explored the potential synergies and the challenges to realizing these synergies in Cameroon. The FLEGT-VPA adopts legality-based safeguards with legally binding monitoring and reporting obligations, whereas REDD+ mainly takes a right-based approach to safeguards. Consultation is the defining form of participation in both processes. REDD+ proposes to develop both vertical and horizontal benefit sharing arrangements, whereas the aim of the VPA is to primarily target the vertical distribution of benefits. Potential synergies exist in the participatory nature of the process of designing benefit sharing mechanisms, strengthening forest and land tenure, and defining the criteria and indicators in relation to FLEGT-VPA and REDD+ safeguards. However, realizing the synergies is challenging given the existing political economy of Cameroon.

Our analysis has also shown that the planned safeguards of neither FLEGT-VPA nor REDD+ will in practice be able to effectively safeguard IPs and local communities. There is rather a real risk that associated funding from the World Bank, UN-REDD and the EU will likely serve the vested interests of powerful individuals in Cameroon. One possible solution to this problem is an overhaul of the land tenure and forestry laws. This conclusion is consistent with that of Mbatu (2015)and Tieguhong et al. (2015). In this regard, a key synergetic point between FLEGT-VPA and REDD+ safeguards is participatory governance reform to clarify the rights to land and natural resources. Given the weak governance in Cameroon, it is essential that the FLEGT and REDD+ actors, CSOs and donors take appropriate steps to ensure that such reform processes adhere to the joint FCPF and UN-REDD+ guidelines on stakeholder engagement and serve the 
interests of IPs and local communities, rather than powerful elites. In addition, the actors must listen to and act on the concerns and constructive proposals of IPs and local communities and ensure their active participation, according to the principles of FPIC. By so doing, a safeguard system and benefit sharing mechanisms that are regarded by stakeholders as effective and equitable can be developed, and this in turn will promote the sustainability and legitimacy of FLEGT and REDD+ processes. Finally, the insights from our analysis can support the development of a way forward for those stakeholders that are willing to realize and contribute to synergetic links between the FLEGT-VPA and the REDD+ safeguards.

\section{Acknowledgments}

Funding for the field work was received from the University of Helsinki. This study was implemented partly in assistance of the SAFARI project. SAFARI is conducted by the European Forest Institute, University of Hamburg and University of Leuven and financed by the German Federal Ministry for Food and Agriculture (BMEL). The authors would like to thank all experts who participated in the interview survey and focus group discussions. The manuscript has benefited from the constructive comments by two anonymous reviewers and the editor. 


\section{References}

Achard, F., Beuchle, R., Mayaux, P., Stibig, H.J., Bodart, C., Brink, A., Carboni, S., Descl??e, B., Donnay, F., Eva, H.D., Lupi, A., Rasi, R., Seliger, R., Simonetti, D., 2014. Determination of tropical deforestation rates and related carbon losses from 1990 to 2010. Glob. Chang. Biol. 20, 25402554. doi:10.1111/gcb.12605

Alemagi, D., Kozak, R.A., 2010. Illegal logging in Cameroon: Causes and the path forward. For. Policy Econ. 12, 554-561. doi:10.1016/j.forpol.2010.07.008

Angelsen, A., Brockhaus, M., Sunderlin, W.D., Verchot, L.V. (Eds), 2012. Analysing REDD+: Challenges and choices 426p. doi:10.17528/cifor/003805

Arhin, A.A., 2014. Safeguards and dangerguards: A framework for unpacking the black box of safeguards for REDD+. For. Policy Econ. 45, 24-31. doi:10.1016/j.forpol.2014.05.003

Arnstein, S.R., 1969. A ladder of citizen participation. J. Am. Inst. Plann. 35, 216-224.

Assembe-Mvondo, S., Colfer, C.J.P., Brockhaus, M., Tsanga, R., 2014. Review of the legal ownership status of national lands in Cameroon: A more nuanced view. Dev. Stud. Res. 1, 148-160. doi:10.1080/21665095.2014.927739

Assembe-mvondo, S., Wongo, G., Loft, L., Tjajadi, J.S., 2015. Comparative assessment of forest revenue redistribution mechanisms in Cameroon Lessons for REDD + benefit sharing.

Awono, A., Somorin, O.A., Eba, R., Levang, P., 2013. Tenure and participation in local REDD + projects : Insights from southern Cameroon. Environ. Sci. Policy 35, 76-86. doi:10.1016/j.envsci.2013.01.017

Bedford, T., Burgess, J., 2001. The focus-group experience, in: Limb, M., Dwyer, C. (Eds.), Qualitative Methodologies for Geographers. Arnold, London, UK.

Blom, B., Sunderland, T., Murdiyarso, D., 2010. Getting REDD to work locally: lessons learned from integrated conservation and development projects. Environ. Sci. Policy 13, 164-172. doi:10.1016/j.envsci.2010.01.002

Brack, D., Léger, C., 2013. Exploring credibility gaps in Voluntary Partnership Agreements: a review of independent monitoring initiatives and lessons to learn.

Brockhaus, M., Di Gregorio, M., Mardiah, S., 2014. Governing the design of national REDD +: An analysis of the power of agency. For. Policy Econ. 49, 23-33. doi:10.1016/j.forpol.2013.07.003

Broekhoven, G., Wit, M. (Eds.), 2014. Linking FLEGT and REDD + to Improve Forest Governance. Tropenbos International, Wageningen, the Netherlands.

Cadman, T., Maraseni, T., Breakey, H., López-Casero, F., Ma, H., 2016. Governance Values in the Climate Change Regime: Stakeholder Perceptions of REDD+ Legitimacy at the National Level. Forests 7, 212. doi:10.3390/f7100212

Cameroon VPA, 2010. EU-Cameroon FLEGT Voluntary Partnership Agreement between Cameroon and the European Union.

Carodenuto, S., Cerutti, P.O., 2014. Forest Law Enforcement, Governance and Trade (FLEGT) in Cameroon: Perceived private sector benefits from VPA implementation. For. Policy Econ. 48, 55-62. doi:10.1016/j.forpol.2014.07.010

Carodenuto, S., Fobissie, K., 2015. Operationalizing Free, Prior and Informed Consent (FPIC) for REDD+: Insights from the National FPIC Guidelines of Cameroon. Carbon Clim. Law Rev. 9, 156167.

Cerbu, G.A., Sonwa, D.J., Pokorny, B., 2013. Opportunities for and capacity barriers to the 
implementation of REDD + projects with smallholder farmers : Case study of Awae and Akok , Centre and South Regions, Cameroon. For. Policy Econ. 36, 60-70. doi:10.1016/j.forpol.2013.06.018

Chhatre, A., Lakhanpal, S., Larson, A.M., Nelson, F., Ojha, H., Rao, J., 2012. Social safeguards and cobenefits in REDD+: A review of the adjacent possible. Curr. Opin. Environ. Sustain. 4, 654-660. doi:10.1016/j.cosust.2012.08.006

Chomba, S., Kariuki, J., Lund, J.F., Sinclair, F., 2016. Roots of inequity: How the implementation of REDD+ reinforces past injustices. Land use policy 50, 202-213. doi:10.1016/j.landusepol.2015.09.021

COMIFAC, 2013. The forests of the Congo Basin 2013: state of the Forest 2013. Weyrich.

Corbera, E., Schroeder, H., 2011. Governing and implementing REDD+. Environ. Sci. Policy 14, 89-99. doi:10.1016/j.envsci.2010.11.002

Duguma, L.A., Minang, P.A., van Noordwijk, M., 2014a. Climate Change Mitigation and Adaptation in the Land Use Sector : From Complementarity to Synergy Climate Change Mitigation and Adaptation in the Land Use Sector : From Complementarity to Synergy. Environmetal Manag. 54, 420-32. doi:10.1007/s00267-014-0331-x

Duguma, L.A., Wambugu, S.W., Minang, P.A., van Noordwijk, M., 2014b. A systematic analysis of enabling conditions for synergy between climate change mitigation and adaptation measures in developing countries. Environ. Sci. Policy 42, 138-148. doi:10.1016/j.envsci.2014.06.003

Dunlop, T., Corbera, E., 2016. Incentivizing REDD+: How developing countries are laying the groundwork for benefit-sharing. Environ. Sci. Policy 63, 44-54. doi:10.1016/j.envsci.2016.04.018

Eba'a Atyi, R., Assembe-Mvondo, S., Lescuyer, G., Cerutti, P., 2013. Impacts of international timber procurement policies on Central Africa's forestry sector: The case of Cameroon. For. Policy Econ. 32, 40-48. doi:10.1016/j.forpol.2012.12.006

EFI, 2012. Guidelines for developing legality definitions in FLEGT Voluntary Partnership Agreements. European Forest Institute.

EMG-UNEP, 2010. Options for environmental and social safeguards in the UN system: a preliminary view. Working draft.

European Commission, 2007. FLEGT briefing notes: Forest Law Enforcement, Governance and Trade. Briefing Notes Number 6.

European Commission, 2003. Communication from the Commission to the Council and the European Parliament Forest Law Enforcement, Governance and Trade (FLEGT) proposal for an EU Action Plan, COM (2003) 251 final.

FCPF, 2010. Guidelines and generic Terms of Reference for SESAs and ESMF. Annexes to the R-PP V.5 draft revised.

FCPF-UNREDD, 2012. Guidelines on stakeholder engagement in REDD+ Readiness with a focus on the participation of indigenous peoples and other forest-dependent communities 22 .

Fobissie, B.K., Essomba, E.P., Sonne, N., Ndobé, S.N., Retana, V., 2012. Social safeguards and the rights of indigenous peoples in the REDD+ process of Cameroon: lessons from experiences in natural resources managment.

Fobissie, K., 2014. Experiences and Lessons Learned on REDD + Social and Governance Safeguards in Cameroon.

Fobissie, K., Alemagi, D., Minang, P.A., 2014. REDD+ policy approaches in the Congo Basin: A 
comparative analysis of cameroon and the Democratic Republic of Congo (DRC). Forests 5, 2400-2424. doi:10.3390/f5102400

Foundjem-Tita, D., Speelman, S., D'Haese, M., Degrande, A., Van Huylenbroeck, G., Van Damme, P., Tchoundjeu, Z., 2014. A tale of transaction costs and forest law compliance: Trade permits for Non Timber Forests Products in Cameroon. For. Policy Econ. 38, 132-142. doi:10.1016/j.forpol.2013.08.007

Freudenthal, E., Nnah, S., Kenrick, J., 2011. REDD and Rights in Cameroon: A review of the treatment of indigenous peoples and local communities in policies and projects.

Gehring, T., Oberthür, S., 2009. The causal mechanisms of interaction between international institutions. Eur. J. Int. Relations 15, 125-156. doi:10.1177/1354066108100055

Hajjar, R., 2015. Advancing small-scale forestry under FLEGT and REDD in Ghana. For. Policy Econ. 58, 12-20. doi:10.1016/j.forpol.2014.09.014

Hall, A., 2007. Social policies at the World Bank : paradigms and challenges Global Social Policy. Glob. Sci. Policy 7, 151-175. doi:10.1177/1468018107078160

Hayes, T., Persha, L., 2010. Nesting local forestry initiatives: Revisiting community forest management in a REDD+ world. For. Policy Econ. 12, 545-553. doi:10.1016/j.forpol.2010.07.003

Jagger, P., Brockhaus, M., Duchelle, A., Gebara, M., Lawlor, K., Resosudarmo, I., Sunderlin, W., 2014. Multi-Level Policy Dialogues, Processes, and Actions: Challenges and Opportunities for National REDD+ Safeguards Measurement, Reporting, and Verification (MRV). Forests 5, 2136-2162. doi:10.3390/f5092136

Karsenty, A., Ongolo, S., 2012. Can "fragile states" decide to reduce their deforestation? The inappropriate use of the theory of incentives with respect to the REDD mechanism. For. Policy Econ. 18, 38-45. doi:10.1016/j.forpol.2011.05.006

Korwin, S., Rey, D., 2015. The role of the legal framework in ensuring REDD + activities are consistent with the UNFCCC REDD + safeguards : Country experiences implementing a Country Safeguard Approach Table of Content.

Lawlor, K., Madeira, E.M., Blockhus, J., Ganz, D.J., 2013. Community participation and benefits in REDD+: A review of initial outcomes and lessons. Forests 4, 296-318. doi:10.3390/f4020296

Lesniewska, F., McDermott, C.L., 2014. FLEGT VPAs: Laying a pathway to sustainability via legality lessons from Ghana and Indonesia. For. Policy Econ. 48, 16-23. doi:10.1016/j.forpol.2014.01.005

Lindhjem, H., Aronsen, I., Bråten, K.G., Gleinsvik, A., 2011. Experiences with benefit sharing: issues and options for REDD+. Oslo, Norway: Econ Pöyry. doi:10.1017/CBO9781107415324.004

Marfo, E., Danso, E., Nketiah, S.K., 2013. Analysis of linkages and opportunities for synergies between FLEGT, REDD and national forest programme in Ghana, Tropenbos International Ghana.

Mbatu, R.S., 2015. Domestic and international forest regime nexus in Cameroon : An assessment of the effectiveness of REDD + policy design strategy in the context of the climate change regime. For. Policy Econ. 52, 46-56. doi:10.1016/j.forpol.2014.12.012

McDermott, C.L., Coad, L., Helfgott, A., Schroeder, H., 2012. Operationalizing social safeguards in REDD+: Actors, interests and ideas. Environ. Sci. Policy 21, 63-72. doi:10.1016/j.envsci.2012.02.007

MINEPDED, 2014. Operational guidelines for obtaining Free, Prior and Informed Concent in REDD+ 
intiatives in Cameroon.

MINEPDED, 2013. REDD+ Readiness Preparation Proposal Cameroon. Submitted to FCPF.

Movuh, M.C.Y., 2012. The Colonial heritage and post-Colonial in $\mathrm{fl}$ uence, entanglements and implications of the concept of community forestry by the example of Cameroon. For. Policy Econ. 15, 70-77. doi:10.1016/j.forpol.2011.05.004

Nkemnyi, M.F., De Herdt, T., Chuyong, G.B., Vanwing, T., 2016. Reconstituting the role of indigenous structures in protected forest management in Cameroon. For. Policy Econ. 67, 45-51. doi:10.1016/j.forpol.2016.03.012

Ochieng, R.M., Visseren-hamakers, I.J., Nketiah, K.S., 2013. Interaction between the FLEGT-VPA and REDD + in Ghana : Recommendations for interaction management. For. Policy Econ. 32, 32-39. doi:10.1016/j.forpol.2012.07.003

Ongolo, S., 2015. On the banality of forest governance fragmentation: exploring gecko politics" as a bureaucratic behaviour in limited statehood. For. Policy Econ. 53, 12-20. doi:10.1016/j.forpol.2015.01.005

Ramcilovic-Suominen, S., Hansen, C.P., 2012. Why some forest rules are obeyed and others violated by farmers in Ghana: Instrumental and normative perspective of forest law compliance. For. Policy Econ. 23, 46-54. doi:10.1016/j.forpol.2012.07.002

Rey, D., Swan, S., Enright, A., 2013. A country-led approach to REDD + safeguards and multiple benefits.

Ros-Tonen, M.A.F., Insaidoo, T.F.G., Acheampong, E., 2013. Promising start, bleak outlook: The role of Ghana's modified taungya system as a social safeguard in timber legality processes. For. Policy Econ. 32, 57-67. doi:10.1016/j.forpol.2012.11.011

Schlager, E., Ostrom, E., 1992. Property-Rights Regimes and Natural Resources : A Conceptual Analysis Edella Schlager and Elinor Ostrom. Land Econ. 68, 249-262.

Somorin, O., Visseren-Hamakers, I.J., Arts, B., Sonwa, D.J., Tiani, A.M., 2014. REDD+ policy strategy in Cameroon: Actors, institutions and governance. Environ. Sci. Policy 35, 87-97. doi:10.1016/j.envsci.2013.02.004

Sunderlin, W.D., Larson, A.M., Duchelle, A.E., Resosudarmo, I.A.P., Huynh, T.B., Awono, A., Dokken, T., 2014. How are REDD+ Proponents Addressing Tenure Problems? Evidence from Brazil, Cameroon, Tanzania, Indonesia, and Vietnam. World Dev. 55, 37-52. doi:10.1016/j.worlddev.2013.01.013

Tacconi, L., 2007. Illegal logging: law enforcement, livelihoods and the timber trade. Earthscan, London.

Tegegne, Y.T., 2016. FLEGT and REDD+ synergies and impacts in the Congo Basin: lessons for global forest governance. University of Helsinki. PhD thesis.

Tegegne, Y.T., Lindner, M., Fobissie, K., Kanninen, M., 2016. Evolution of drivers of deforestation and forest degradation in the Congo Basin forests: Exploring possible policy options to address forest loss. Land use policy 51, 312-324. doi:10.1016/j.landusepol.2015.11.024

Tegegne, Y.T., Ochieng, R.M., Visseren-Hamakers, I.J., Lindner, M., Fobissie, K.B., 2014. Comparative analysis of the Interactions between the FLEGT and REDD+ regimes in Cameroon and the Republic of Congo. Int. For. Rev. 16, 602-614. doi:10.1505/146554814814095311

Tegegne, Y.T., Van Brusselen, J., Tuomasjukka, D., Lindner, M., 2014. Proposing an indicator framework for FLEGT voluntary partnership agreements impact monitoring. Ecol. Indic. 46, 487-494. doi:10.1016/j.ecolind.2014.07.020 
Tieguhong, J.C., Ingram, V., Mala, W.A., Ndoye, O., Grouwels, S., 2015. How governance impacts non-timber forest product value chains in Cameroon. For. Policy Econ. 61, 1-10. doi:10.1016/j.forpol.2015.08.003

UNFCCC, 2011. The Cancun Agreements Dec 1/CP. 16. United Nations Framework Convention on Climate Change.

van Heeswijk, L., Turnhout, E., 2013. The discursive structure of FLEGT (Forest Law Enforcement, Governance and Trade): The negotiation and interpretation of legality in the EU and Indonesia. For. Policy Econ. 32, 6-13. doi:10.1016/j.forpol.2012.10.009

Visseren-Hamakers, I.J., Gupta, A., Herold, M., Peña-Claros, M., Vijge, M.J., 2012. Interdisciplinary perspectives on REDD+. Curr. Opin. Environ. Sustain. 4, 587-589. doi:10.1016/j.cosust.2012.10.011

Wiersum, K.F., Elands, B.H.M., 2013. Opinions on legality principles considered in the FLEGT/VPA policy in Ghana and Indonesia. For. Policy Econ. 32, 14-22. doi:10.1016/j.forpol.2012.08.004

Willis, J., Venant, M., Noel, O., 2016. The rights of Baka communities in the REDD+ Ngoyla-Mintom project in Cameroon.

Wodschow, A., Nathan, I., Cerutti, P., 2016. Participation, public policy-making, and legitimacy in the EU Voluntary Partnership Agreement process: The Cameroon case. For. Policy Econ. 63, 1-10. doi:10.1016/j.forpol.2015.12.001

World Bank, 2005. The World Bank Operations Manual. The World Bank, New York, pp. 1553. 